\title{
Effects of the Location of GSM Base Stations on Satisfaction of Occupiers and Rental Value of Proximate Residential Property
}

\author{
M. O. BELLO PhD \\ Department Of Estate Management \\ Federal University of Technology Akure, Nigeria \\ E-mail: oyewolebello@yahoo.com; oyewolebello@journalanduse.org
}

\begin{abstract}
The introduction of Global System for Mobile Communications (GSM) phone with the un-regulated sitting of communication towers had increased the exposure of great percentage of the population to electromagnetic radiation and the concomitants health hazard in developing countries.

With samples from Akure Nigeria, the study examined the variation of the satisfaction of the people living around GSM base stations with distance away from the location of the base station. Using Crosstabs' nominal-by-nominal measures, the study found that the further the distances away from the base station, the higher the percentages of those that are satisfied; When the effect of fear of health problems exhibited by the residents was introduced, the study found that the variation in the satisfaction level with distance was due to those who haboured fear of health problems. In addition, the study used Ordered Logit Regression to model the combined effects of distance, fear and rent on the satisfaction with base station location; in this wise; the study found that statistically significant relationship exists between Distance and satisfaction with the base station. To alleviate the real and perceived fear associated with the location of base station therefore, the residents should be provided with unbiased factual information relating to the negative effects on health and other hazards associated with living in close proximity to a base station.
\end{abstract}

Keywords: Base Station, Satisfaction, Rental Value, Crosstabulation, Fear

\section{Introduction}

The sitting of GSM Base Stations within communities has continued to generate strong concerns. The opposition that initially started from the developed countries is fast spreading to the developing countries as well (Igbokwe, 2006). This notwithstanding, GSM has become a vital and an indispensable tool of transmitting or exchanging of information for a modern man. Not only that, it is a significant infrastructure that promotes the growth and development in any facets of man's activities such as agriculture, education, industry, banking, transportation etc. In fact, it is an essential tool for man to function well in all his endeavours. With the advent of GSM, the rates, rigours and risks of travelling have been greatly reduced, the ease and speed of business transactions have been raised to an unprecedented level and lives have been saved at the nick of time in times of emergency or disaster. The aforementioned benefits are not without corresponding social costs. Foremost among these are safety, health hazards, aesthetics, degraded viewscape, reduced property values among others. Some of these social costs are attributable to the usage of the Cell Phone while the majority are linked with living or working around a Base Station.

Unfortunately, at Present, it is not technologically feasible to have mobile telephone without Base Stations. To communicate with each other, mobile phones and base stations must exchange signals. When a call is made, the microphone of the mobile phone converts voice into electrical signals. These signals are sent to base station antennas. Once the signals reach a radio base station, "it is sent across the mobile operator's network to a switch or exchange where it is transferred to the destination customer." The nearest base station antennas of the destination customer emit these signals, which are then received by his mobile phone, which convert these to sound by the speaker. The antenna of a base station cover a restricted geographical area called cell. The cell covered by a base station depends on the call usage and the physical terrain of the area. Phone calls signals pass from one cell to another through an underground fibre optic cable or via a "point- to - point" fixed microwave beam, which require a direct line of sight. In order to make it possible for the customer on the move to continuously make or receive a call, the cells must necessarily overlap.

Besides, the base stations are sited in close proximity to inhabited areas, because; the farther, the equipment is located away from the users, the poorer will be the quality of communication. Secondly, if the equipment is placed too far from the user, this will cause the phones to increase their output power in order to sustain the connection and thus decreasing the battery life and talk time. The basic fact is that "there are practical limitations to the 
geographic area that a base station can effectively serve and a limit to the number of calls it can accommodate at a point in time (Mobile Manufactures Forum and GSM Association, 2006).

\section{Fear Originating from Health Effects of Electromagnetic Radiation from Mobile Phone Signals}

Since a base station must be sited in close proximity to inhabited areas, the main concern here is the Radio Frequency (RF) emissions from these Base Stations. This is because R F is absorbed into human bodies, which may produce a heating effect depending on the intensity of exposure. There is no controversy about this thermal effect; however, the non-thermal effects have continued to be the subject of controversies between researchers, the mobile phone operators, the communities and a host of other stake holders. The mobile phone operators and government authorities have consistently insisted that cell phones are perfectly safe and the radiations from it are no more dangerous than any other radio signal (Stewart, 2000; WHO, 1993, WHO, 2001; Mobile Manufactures Forum and GSM Association, 2006). However, reported scientific evidences have continued to challene this position. Some of these studies are summarised in table 1. According to Cherry (2000), over 40 studies have shown adverse biological or human health effects specifically from cell phone radiation. "These research results to date clearly show that cell phones and cell phone radiation are a strong risk factor for all of the adverse health effects identified for Electro Magnetic Radiation (EMR) because they share the same biological mechanisms." In this wise, Cherry (2000) observed that there is extremely strong evidence to conclude that mobile phone Base Stations are risk factors for:

- Cancer, especially brain tumour and leukaemia, but all other cancers also.

- Cardiac arrhythmia, heart attack and heart disease, particularly arrhythmia.

- Neurological effects, including sleep disturbance, learning difficulties, depression and suicide.

- Reproductive effects, especially miscarriage and congenital malformation.

- Viral and infectious diseases because of reduce immune system competency as associated with reduced melatonin and altered calcium ion homeostasis.

\section{GSM Base Station and Property Value}

The growing concerns of the general public over the effects of the Base Stations on property values stems from the concerns about the negative effect it impacts on health, safety and the visual effects of the towers. While experimental and epidemiological studies focus on the adverse health effects of radiation from the use of Cell Phones and Base Stations, few studies have been conducted to ascertain the effects of Base Stations on property values. Bond et al (2003) found that people whom live close to a base station perceive the sites less negatively than those whom live further away. Although he did not established any significant effect of the location of base station on property values, however he is of the opinion that the only reason a rational investor might continue to avoid property near a cell site would be because it was intrusive on the views received from the property or because of the adverse aesthetic effects of the Cell Phone Base Station on the property.

Picard (1996) reported that there are at least two instances in Canada where the assessed value of residential properties were reduced due to close proximity to commercial antenna towers. The justification for the reduction was the impact of the tower upon the aesthetics' of the neighbouring lands. In Colwood, British Columbia, the assessed values of sixteen residential properties were reduced by an average of $7.2 \%$ due to the aesthetic impact of a broadcasting antenna installation (Macdonald, 2001).

The impact of communication towers on property value and community health is fast becoming a matter for legal tussles between the community, property owners and the wireless service provider (see Cellular Telephone Co Vs. Oyster Bay, (166 F. 3d 490, 2d Cir. 1999); Sprint Spectrum LP Vs. Willoth (176 F. 3d 630 2d Cir 1999); Mcintyre and others Vs. Christchurch City Council (1996) NZRMA 289; Shirley Primary School Vs Telecom Mobile Communication LTD (1999) NZRMA 66). In most of the cases, while the courts held that there is no sufficient evidence to proof that Base Station may lead to adverse health effects; however the courts conceded that there are evidences of property values being affected.

The fall zone argument is another point of claim on property values. The point being made here is that proximate properties face the risk of being crushed down because of a falling tower. This has been proved to be a genuine case for concern especially in Nigeria; for instance, According to Igbokwe, (2006), the Lagos State Infrastructure Maintenance Regulatory Agency got a report of a collapsed mast in front of a police station at Iyana Ipaja, near Total Filling Station. "We are lucky that the mast fell on a huge three-dimensioned iron bill board. Lives would have been lost and property destroyed if it had fallen on the ground". The concern for the fall zone has made most cities and municipalities to insist on a sufficient set back between a tower and the nearest property line. In Ohio, the 
guidelines required that if a tower is less than 75 feet tall, the site must have a 250 feet set back from the nearest property line. If the tower is 75 to 150 feet tall, the site has to have a 500 feet set back. Any tower more than 150 feet must have a 750 feet set back from the nearest property line (Primedia, 2004).

In Nigeria, there is proliferation of service providers with each one struggling to outdo the other in the attempts to capture as much as possible from the ever growing demand. The consequent is the indiscriminate siting of base station and communication anteneas. Unfortunately, the effect of these on the properties and the people living around these installations has not been extensively studied. It is in the light of this, that this paper is tailored to address primarily, the satisfaction level of people living around the GSM Base Stations.

\section{Methodology}

The data for this study were drawn from a sample of occupiers of residential properties located within 300 meters radius to each of five (5) base stations in Akure. A random sample of 15 houses was taken each at estimated distance of less than $100 \mathrm{~m}, 101 \mathrm{~m}-200 \mathrm{~m}, 201 \mathrm{~m}-300 \mathrm{~m}$, and above $300 \mathrm{~m}$ away from each base station. In each of the selected houses, questionnaire was administered to an occupant, in all; three hundred (300) respondents from five (5) base stations were investigated. Only 212 questionnaires were good for analysis. The major question areas include: their satisfaction with the location of the base station in their neihgborhood, whether or not they harbour fear of loosing their health due to the sitting of the base station in the area and whether or not they are satisfied with the rent paid for the property they occupied. These variables are described as contained in table 2

The analysis was done at four levels as follows:

i. the relationship between satisfaction with the base station location and distance away from the base station,

ii. the effect of fear exhibited by the residents on their satisfaction with the base station location,

iii. the relationship between satisfaction with the base station location and satisfaction with the rent paid, and;

iv. the combined effects of distance, fear and satisfaction with rent on the satisfaction with base station location.

The choice of the methods of analysis was primarily anchored on the categorical nature of the data. In this regard, Cross tabulation was used to determine the significance and strenght of the relationships between the variables (i.e. items i-iii), in this wise, chi square was employed to determine the significance of the relationship while, Directional and Symetric Measures were used to assess the strenght of the relationships.

In other to assess the combined effects of distance, fear and satisfaction with rent on the satisfaction with base station location, Ordered Logit Regression was employed. Ordered Logit Regression is an Ordered Dependent Variable Models in which the observed $y$ denotes outcomes representing ordered or ranked categories. The observed is modelled by considering a latent variable $y_{i}^{*}$ that depends linearly on the explanatory variables $x_{i}$

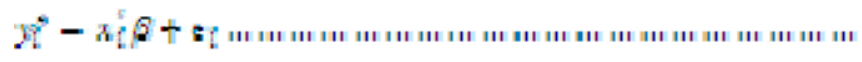

where $x_{i} \epsilon_{i}$ are independent and identically distributed random variables. The observed $\mathrm{y}_{\mathrm{i}}$ is determined from $y_{i}^{*}$ using the rule:

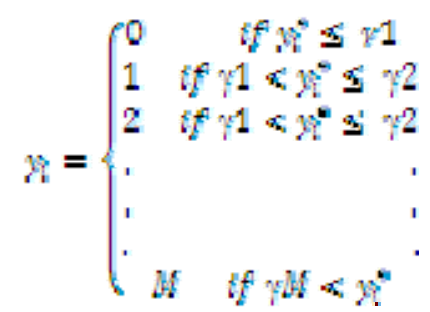

It follows that the probabilities of observing each value of $y$ are given by

$$
\begin{aligned}
& F r\left(n=0 \mid x_{0} \beta, \gamma\right)=F\left(\gamma 1-x_{1}^{*}\right) \\
& \operatorname{Pr}\left(\gamma=1 \mid x_{i} \beta, \gamma\right)=F\left(\gamma 2-x_{i} \beta\right)-F\left(\gamma 1-x_{i} \mid \gamma\right) \\
& \operatorname{Pr}\left(x=2 \mid x_{2} \beta, \gamma\right)=F\left(\gamma \beta-x_{1} \beta\right)-F\left(\gamma^{2}-x_{1} \beta\right) \\
& F r\left(\gamma=M \mid x_{\theta} \beta \gamma\right)=1-F\left(\gamma \mathrm{M}-x_{1} \beta\right)
\end{aligned}
$$


where $\mathrm{F}$ is the Cumulative Distribution Function of $\epsilon_{i}$.

The threshold values $\gamma$ are estimated along with the $\beta$ coefficients by maximizing the Log Likelihood Function:

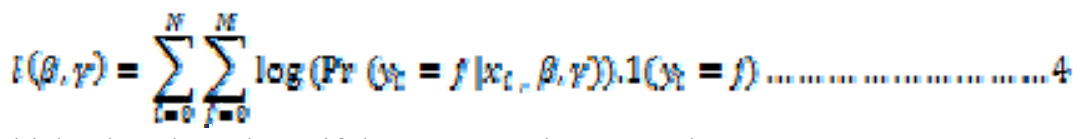

Where $1($.$) is an indicator function which takes the value 1$ if the argument is true, and 0

if the argument is false. For this study, the Ordered Regressand is the Satisfaction of the Residents around the Base station, while the regressors are: the distance away from the base station, fear of loosing health and satisfaction with the rent paid.

\section{Data Analysis and Discussion of Results}

Table 3 shows the results of the cross tabulation of the relationship between satisfaction with the location of base station and distance away from it. From this table, the total percentages of those that are not satisfied (i.e. a combination of highly not satisfied with those that are somewhat not satisfied) for distances less than $100 \mathrm{~m}$, $101 \mathrm{~m}-200 \mathrm{~m}, 201 \mathrm{~m}-300 \mathrm{~m}$ and above $300 \mathrm{~m}$ are $47.6 \%, 38 \%, 32.7 \%$, and $32.3 \%$ respectively; this implies that, the further away the distance from the base station, the lower the number of those who are not satisfied. On the other hand, the further away the distances away from the base station, the higher the percentages of those that are satisfied; for distances less than $100 \mathrm{~m}, 101 \mathrm{~m}-200 \mathrm{~m}, 201 \mathrm{~m}-300 \mathrm{~m}$ and above $300 \mathrm{~m}$, the percentages of those that are satisfied (i.e. a combination of highly satisfied with those that are somewhat satisfied) are $26.1 \%, 28 \%, 46.6 \%$ and $54.8 \%$ respectively. The two-sided asymptotic significance of the chi-square statistic is less than 0.05 (Table 4), so it's safe to say that the observed variations in these percentages accross the distances are not due to chance. This implies that occupants at different kilometer away from the base station have different levels of satisfaction. While the values of the chi-square tests indicates a significant relationship; Symmetric measures shows the strength of this relationship. The significance values of all the three Symmetric measures from Table 5 are 0.006, further confirming a statistically significant relationship. However, the values of all the three measures are small (Phi $=0.360$, Cramers V $=0.208$, and Contingency Coefficient $=0.339$ ), indicating that, although the relationship is not due to chance, it is also not very strong.

When the the effect of fear of health problems exhibited by the residents was introduced, the previous crosstabulation (Table 3) is now split into two parts as shown in table 6 . The significance values of the tests (Table 7) (Pearson $=0.006$, Likelyhood Ratio $=0.004$ ) for Occupants who harboured fear of health problem are less than 0.05 , the relationship observed in the crosstabulation (Table 6) is therefore, real and not due to chance. The same thing can not be said of those who did no habour any fear; in which case, the significant values (Pearson $=0.736$, Likelyhood Ratio $=0.675$ ) are greater than 0.05 . Hence we can conclude that the variation in the satisfaction level with distance is due to those who haboured fear of health problems.

The next factor which was considered was if the satisfaction experienced had a relationship with the rent paid. In other words, wheher the satisfaction with the location of the base station could be attributable to the satisfaction with the rent paid. The rent paid here is assumed to be a factor of the building quality and other environmental variables with the exception of influence of the base station location. In this wise, table 8,9 show the crosstabulation between Distance from base station and satisfaction with rent paid and the Chi-square statistics; while table 10 and 11 show the crosstabulation between satisfaction with the base station and satisfaction with rent paid the Chi-square statistics. From table 9, all the significant tests (Pearsons Chi-square=0.832, Likelihood Ratio $=0.811$, and Linear-by-Linear Association $=0.688$ ) are above 0.05 , hence we can conclude that a statiscally significant relationship does not exist between Distance from base station and Satisfaction with rent paid. The same inference can be made from table 11, all the significant tests (Pearsons Chi-square $=0.519$, Likelihood Ratio $=0.423$, and Linear-by-Linear Association $=0.405$ ) are above 0.05 , hence we can conclude that a statiscally significant relationship does not exist between satisfaction with the base station location and satisfaction with rent paid. ,

Using Ordered Logit Regression to model the combined effects of distance, fear and satisfaction with rent on the satisfaction with base station location. the results is presented in Table 12.

In this type of Regression model, "goodness of fit is of secondary importance, what matters is the expected signs of the regression coefficients and their statistical and /or practical significance"(Gujarati and Sangeetha, 2007). From table.12, Fear and Distance are positively associated with satisfaction with base station location, while rent is negatively associated. There were no statistically significant effects of Fear and Rent on Satisfaction with base 
station (p-values $>0.05$ ). The only statistically significant relationship is between Distance and satisfaction with the base station. For a one unit increase in Distance, the expected log odds increases by 0.26 as you move to the next higher category of satisfaction with the base station location. Using the predicted probability (anti log of coefficients), this means that as the distance increases from the base station, there are more than 1.46 chance of the occuppier moving to the next higher level of satisfaction.

\section{Conclusion and Recommendation}

The research has examined the variation of the satisfaction of the people living around GSM base station with the distance away from the location of the base station.

The study has established that the location of the base station accompanied by fear haboured by the residents has led to the reduction in the level of their satisfaction. With the increase in the numbers of phone users in the foreseeable future, there will inevitable be increase in the numbers of base station sites. This will definitely lead to more agitations and public concerns for the possible impacts as awareness increases. Therefore, the community should always be involved in any decision to erect a base station in their neighbourhoods. In this wise, they should be provided with unbiased factual information relating to the negative effects on health and other hazards associated with living in close proximity to a base station.

\section{References}

Altamura G., Toscano S., Gentilucci G., Ammirati F., Castro A., Pandozi C., \& Santini M. (1997). Influence of digital and analogue cellular telephones on implanted pacemakers. European Heart Journal 18(10), 1632-4161.

Barbaro V., Bartolini P., Donato A., \& Militello C. (1996). Electromagnetic interference of analog cellular telephones with pacemakers. Pacing and Clinical Electrophysiology 19(10), 1410-1418.

Bello, M. O. (2007). The Impact of Communication Tower on the Host Community and Surrounding Property Values, In Nigeria. In Fadare and Adesanya (eds.) Towards a Sustainable Built and Natural Environment, Obafemi Awolowo University, Ile Ife, Nigeria 328-339

Blake, B Levit. (1998). Cell phone Towers and Communities: The struggle for local control. America Real Estate Society, January- April 2002. Pro Quest Information and Learning Company

Bond Sandy, Si-Yeoul Mun, \& MacMahon N. (2003). The impact of cellular phone base station towers on property values. Ninth Pacific -Rim Real Estate Society Conference, Brisbane, Australia, 19-22 January, 2003

Borbely, A. A., Huber, R., Graf, T., Fuchs, B., Gallmann, E., \& Achermann, P. (1999). Pulsed high-frequency electromagnetic field affects human sleep and sleep electroencephalogram. Neuroscience Letters 275(3):207-210.

Braune, S, Wrocklage, C., Raczek, J., Gailus, T., \& Lucking, C.H. (1998). Resting blood pressure increases during exposure to a radio-frequency electromagnetic field.The Lancet 351(9119),1857-1858.

Chen W.H., Lau C.P., Leung S.K., Ho D.S., \& Lee I.S. (1996). Interference of cellular phones with implanted permanent pacemakers. Clinical Cardiology 19(11), 881-886.

Cherry N. (2000). Health effects associated with mobile base stations in communities: the need for health studies. http://www.neilcherry.com/ (accessed date 12/11/2006)

Dasdag, S., Ketani, M.A., Akdag, Z., Ersay, A.R., Sar,i I, Demirtas ,O.C., \& Celik, M.S. (1999). Whole-body microwave exposure emitted by cellular phones and testicular function of rats. Urological Research 27(3)219-223.

Eulitz, C., Ullsperger, P., Freude, G., \& Elbert ,T. (1998). Mobile phones modulate response patterns of human brain activity. Neuroreport $9(14), 3229-3232$.

Freude, G., Ullsperger, P., Eggert ,S., \& Ruppe, I. (1998). Effects of microwaves emitted by cellular phones on human slow brain potentials. Bioelectromagnetics 19(6):384-387.

Gujarati Damodar N.,\& Sangeetha. (2007). Basic Econometrics. The McGraw-Hill Hardell, L., Nasman, A., Pahlson, A., Hallquist, A., \& Hansson Mild, K. (1999). Use of cellular telephones and the risk for brain tumours: A case-control study. International Journal of Oncology 15(1),113-116.

Hardell, L., Nasman, A.,\& Hallquist, A. (2000). Case-control study of radiology work, medical X-ray investigations and use of cellular telephones as risk factors. Journal of General Medicine; www.medscape.com/Medscape/GeneralMedicine/journal/2000/v02.n03/>

Hladky, A., Musil, J., Roth, Z., Urban, P., \& Blazkova, V. (1999). Acute effects of using a mobile phone on CNS functions. Central European Journal of Public Health 7(4),165-167.

Hocking, B. (1998). Preliminary report: symptoms associated with mobile phone use. occupational medicine 
48(6):357-360.

Igbokwe joe. (2006). Five Years of GSM in Nigeria. Sunday Sun, August 13;2006

Kellenyi, L., Thuroczy, G., Faludy, B., \& Lenard, L. (1999). Effects of mobile GSM radiotelephone exposure on the auditory brainstem response (ABR). Neurobiology (7),79-81.

Koivisto, M., Revonsuo, A., Krause, C., Haarala, C, Sillanmaki, L., Laine, M., \& Hamalainen, H. (2000). Effects of $902 \mathrm{MHz}$ electromagnetic field emitted by cellular telephones on response times in humans. Neuroreport 11(2),413-415.

Krause, C.M., Sillanmaki, L., Koivisto, M., Haggqvist, A., Saarela, C., Revonsuo, A., Laine, M., \& Hamalainen H. (2000). Effects of electromagnetic field emitted by cellular phones on the EEG during a memory task. Neuroreport 11(4),761-764.

Macdonald C. (1996). Communication towers sitting British Columbia Assessment Policy, Audit and Legal Services . Personal Communication April, 1996.

Mann, K., \& Roschke, J. (1996). Effects of pulsed high-frequency electromagnetic fields on human sleep. Neuropsychobiology 33(1),41-47.

Mild, K..H., Oftedal, G., Sandstrom, M., Wilen, J., Tynes, T., Haugsdal, B. \& Hauger E. (1998). Comparison of symptoms by users of analogue and digital mobile phones - A Swedish-Norwegian epidemiological study. National Institute for working life, 1998; 23, Umea, Sweden, 84.

Mobile Manufacturers Forum and GSM Association. (2006). Mobile Phone Base Stations EMF / Health Fact Pact http://www.gsmworld.com/using/health-paper (accessed date 6/10/2006)

Naegeli B., Osswald S., Deola M., \& Burkart F. (1996). Intermittent pacemaker dysfunction caused by digital mobile telephones. Journal of the American College of Cardiology 27(6),1471-1477.

Occhetta E., Plebani L., Bortnik M., Sacchetti G., \& Trevi G. (1999). Implantable cardioverter defibrillators and cellular telephones: is there any interference? Pacing and Clinical Electrophysiology 22(7), 983-989.

Picard R. (1996). Administrative Assistant, Property Assessment, Ontario Ministry Of Finance. Personal Communication, April 25, 1996

Preece, A.W., Iwi, G., Davies-Smith, A., Wesnes, K., Butler, S., Lim, E., \& Varey, A. (1999). Effect of a 915-MHz simulated mobile phone signal on cognitive function in man. International Journal of Radiation Oncology*Biology*Physics 75(4),447-456.

Repacholi, M.H., Basten, A., Gebski, V., Noonan, D., Finnie, J., \& Harris, A.W. (1997). Lymphomas in E mu-Pim1 transgenic mice exposed to pulsed $900 \mathrm{MHZ}$ electromagnetic fields. Radiation Research 147(5),631-640.

Schlegel R.E., Grant F.H., Raman S., \& Reynolds D. (1998). Electromagnetic compatibility study of the in-vitro interaction of wireless phones with cardiac pacemakers. Biomedical Instrumentation \& Technology 32(6): 645-655.

Stewart W. (2000). Mobiles Phones and Health. Independent Expert Group on Mobile Phones Report To the United Kingdom Government, c/o National Radiological Protection Board, Chilton; Didcot, Oxon OX11 0RQ

http://www.iegmp.org.uk (accessed date 12/11/2006)

Trigano A.J., Azoulay A., Rochdi M., \& Campillo, A. (1999). Electromagnetic interference of external pacemakers by walkie-talkies and digital cellular phones: experimental study. Pacing and Clinical Electrophysiology 22(4 Pt 1): 588-593.

WHO. (1993). Electromagnetic fields (300 Hz to $300 \mathrm{GHz}$ ), Environmental Health Criteria 137, World Health Organization, Geneva

WHO. (2001). "WHO clarifies its position on health effects of mobile phone use". Note for the Press No 1410 October 2001

Von Klitzing, L. (1995). Low-frequency pulsed electromagnetic fields influence EG of man. Physica Medica (European Journal of Medical Physics) (11)77-80. 
Table 1. Effects of Electromagnetic Radiation from Mobile Phone Signals

\begin{tabular}{|c|c|c|}
\hline $\mathrm{S} / \mathrm{NO}$ & EFFECTS & STUDIES \\
\hline 1 & Disturbs Sleep & $\begin{array}{l}\text { - Mann and Roschkle (1996), } \\
\text { - Borbely et al. (1999) }\end{array}$ \\
\hline 2 & Alters human reaction times & $\begin{array}{l}\text { - } \begin{array}{l}\text { Preece et al. (1999), Induced potentials, } \\
\text { - }\end{array} \text { Eulitz et al. (1998), slow brain potentials, } \\
\text { Freude et al. (1998), Response and speed } \\
\text { of switching attention (need for car } \\
\text { driving) significantly worse, } \\
\text { Hladky et al. (1999). Altered reaction } \\
\text { times and working memory function } \\
\text { (positive), .Koivisto et al. (2000), Krause } \\
\text { et al. (2000). } \\
\text { Von Klitzing (1995), Mann and Roschkle } \\
\text { (1996), Krause et al. (2000). }\end{array}$ \\
\hline 3 & Alters brain activity including EEG, & $\begin{array}{l}\text { - Von Klitzing (1995), Mann and Roschkle } \\
\text { (1996), } \\
\text { - Krause et al. (2000). }\end{array}$ \\
\hline 4 & $\begin{array}{l}\text { Increased auditory brainstem response and } \\
\text { hearing deficiency in } 2 \mathrm{khz} \text { to } 10 \mathrm{khz} \text { range }\end{array}$ & - Mild et al. (1998); \\
\hline 5 & $\begin{array}{l}\text { Causes memory loss, concentration difficulties, } \\
\text { fatigue, headache, discomfort, nausea, }\end{array}$ & $\begin{array}{ll} & \text { Mild et al. (1998); } \\
\text { - } & \text { Hocking (1998). } \\
\end{array}$ \\
\hline 6 & Increases human brain tumor & $\begin{array}{l}\text { - Hardel et tal. (1999); } \\
\text { - } \quad \text { Hardell et al. (2000), }\end{array}$ \\
\hline 7 & Cardiac pacemaker interference: & $\begin{array}{ll}\text { - } & \text { Barbaro et al. (1996); } \\
\text { - } & \text { Chen et al. (1996); } \\
\text { - } & \text { Naegeli et al. (1996); } \\
\text { - } & \text { Altamura et al. (1997); } \\
\text { - } & \text { Schlegal et al. (1998); } \\
\text { - } \quad \text { Occhetta et al. (1999); } & \text { Trigano et al. (1999) } \\
\end{array}$ \\
\hline 8 & $\begin{array}{l}\text { Decreases in sperm counts and smaller tube } \\
\text { development in testes }\end{array}$ & - $\quad$ Dasdag et al. (1999). \\
\hline 9 & Increases blood pressure & - $\quad$ Braune et al. (1998) \\
\hline 10 & Doubles the cancer in mice, & - $\quad$ Repacholi et al. (1997). \\
\hline
\end{tabular}

Source: Bello, 2007

Table 2. Variable List And Description

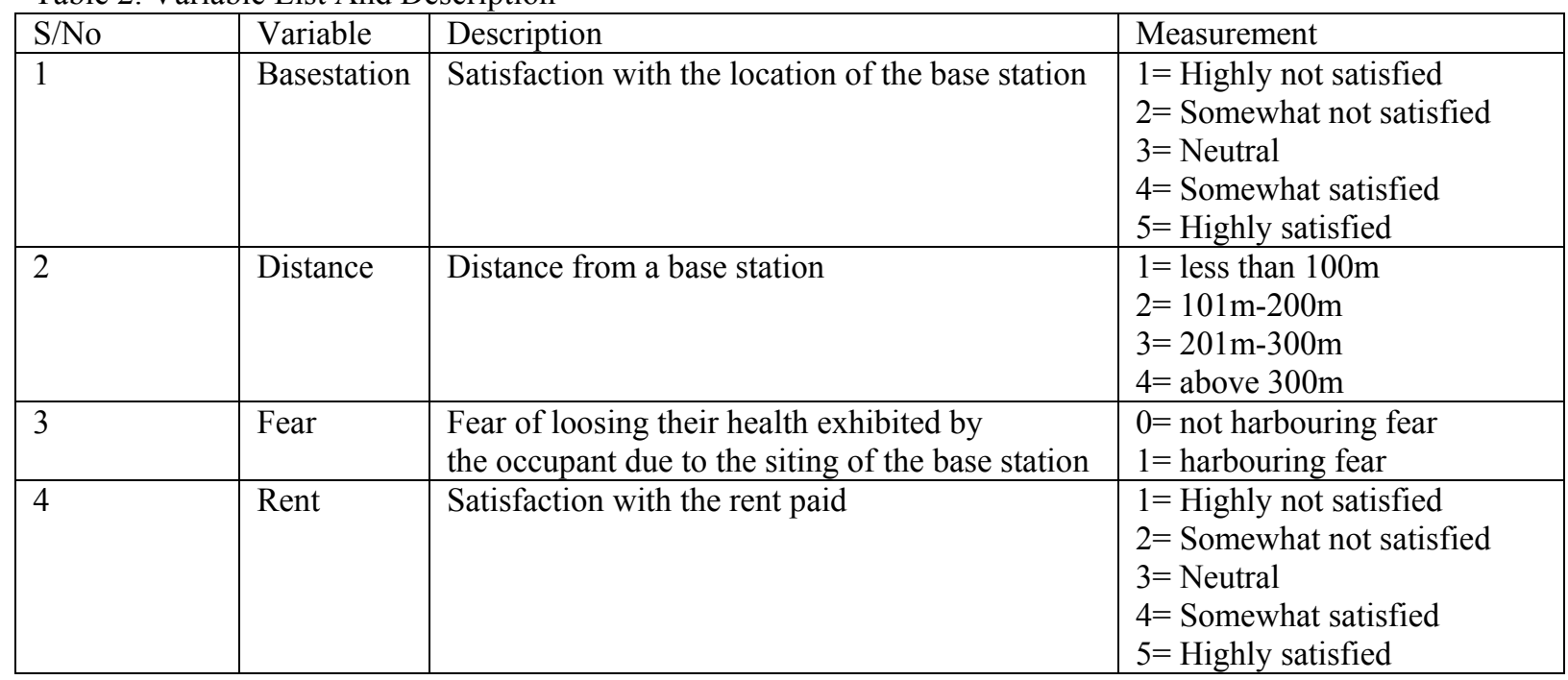


Table 3. Crosstabulation of Distance from base station and satisfaction with base station

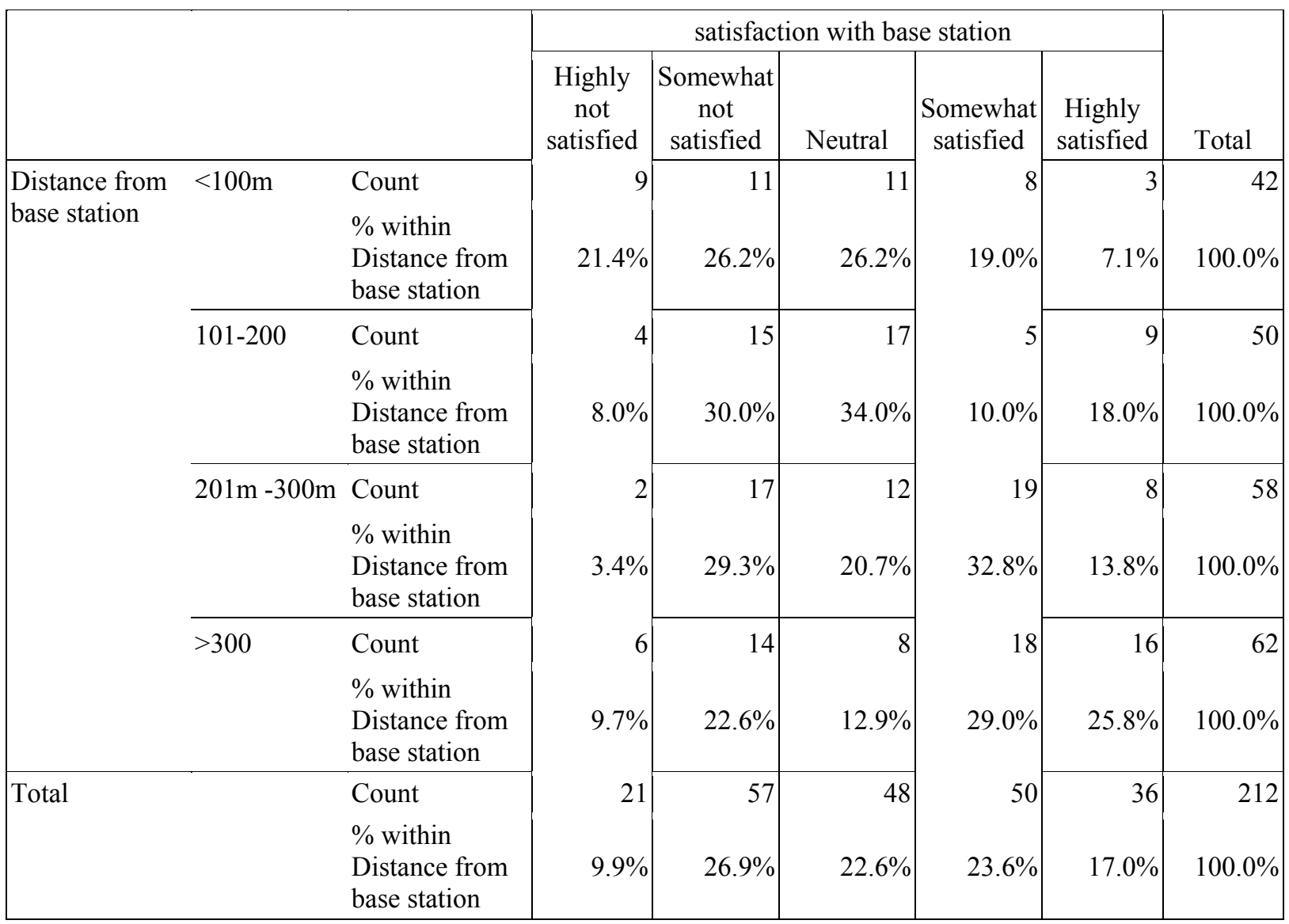

Table 4. Chi-Square Tests

\begin{tabular}{|l|r|r|r|}
\hline & \multicolumn{1}{|c|}{ Value } & Df & \multicolumn{1}{|c|}{$\begin{array}{c}\text { Asymp. Sig. } \\
\text { (2-sided) }\end{array}$} \\
\hline Pearson Chi-Square & $27.521^{\mathrm{a}}$ & 12 & .006 \\
Likelihood Ratio & 28.188 & 12 & .005 \\
Linear-by-Linear & 5.269 & & 1 \\
Association & 212 & & .022 \\
N of Valid Cases & & \\
\hline
\end{tabular}

Table 5. Symmetric Measures

\begin{tabular}{|ll|r|r|}
\hline & & \multicolumn{1}{|c|}{ Value } & Approx. Sig. \\
\hline Nominal by Nominal & Phi & .360 & .006 \\
& Cramer's V & .208 & .006 \\
& Contingency Coefficient & .339 & .006 \\
N of Valid Cases & & 212 & \\
\hline
\end{tabular}


Table 6. The Effects of fear of health problems on satisfaction with base station

\begin{tabular}{|c|c|c|c|c|c|c|c|c|}
\hline \multirow{2}{*}{\multicolumn{3}{|c|}{ Fear Of Health Problems }} & \multicolumn{5}{|c|}{ Satisfaction With Base Station } & \multirow[b]{2}{*}{ Total } \\
\hline & & & $\begin{array}{c}\text { Highly Not } \\
\text { Satisfied }\end{array}$ & $\begin{array}{c}\text { Somewhat } \\
\text { Not Satisfied }\end{array}$ & Neutral & $\begin{array}{c}\text { Somewhat } \\
\text { Satified }\end{array}$ & $\begin{array}{l}\text { Highly } \\
\text { Satisfied }\end{array}$ & \\
\hline $\begin{aligned} \text { No } & \text { Distance } \\
& \text { from base } \\
& \text { station }\end{aligned}$ & $<100 \mathrm{~m}$ & $\begin{array}{l}\text { Count } \\
\% \text { within } \\
\text { Distance from } \\
\text { base station }\end{array}$ & $16.7 \%$ & $27.8 \%$ & $22.2 \%$ & $27.8 \%$ & $5.6 \%$ & $100.0 \%$ \\
\hline & $101-200$ & $\begin{array}{l}\text { Count } \\
\% \text { within } \\
\text { Distance from } \\
\text { base station }\end{array}$ & $14.3 \%$ & $28.6 \%$ & $28.6 \%$ & $14.3 \%$ & $14.3 \%$ & $\begin{array}{r}21 \\
100.0 \%\end{array}$ \\
\hline & $\begin{array}{l}201 \mathrm{~m} \\
-300 \mathrm{~m}\end{array}$ & $\begin{array}{l}\text { Count } \\
\% \text { within } \\
\text { Distance from } \\
\text { base station }\end{array}$ & $2.7 \%$ & $35.1 \%$ & $18.9 \%$ & 10 & $16.2 \%$ & $\begin{array}{r}37 \\
100.0 \%\end{array}$ \\
\hline & $>300$ & $\begin{array}{l}\text { Count } \\
\% \text { within } \\
\text { Distance from } \\
\text { base station }\end{array}$ & $9.4 \%$ & $25.0 \%$ & $18.8 \%$ & $21.9 \%$ & $25.0 \%$ & 32 \\
\hline Total & & $\begin{array}{l}\text { Count } \\
\% \text { within } \\
\text { Distance from } \\
\text { base station }\end{array}$ & $9.3 \%$ & $29.6 \%$ & $21.3 \%$ & $23.1 \%$ & $16.7 \%$ & $\begin{array}{r}108 \\
100.0 \%\end{array}$ \\
\hline \multirow[t]{4}{*}{$\begin{array}{l}\text { Yes Distance } \\
\text { from base } \\
\text { station }\end{array}$} & $<100 \mathrm{~m}$ & $\begin{array}{l}\text { Count } \\
\% \text { within } \\
\text { Distance from } \\
\text { base station } \\
\end{array}$ & $25.0 \%$ & $25.0 \%$ & $29.2 \%$ & $\begin{array}{r}3 \\
12.5 \%\end{array}$ & $\begin{array}{r}2 \\
8.3 \%\end{array}$ & $\begin{array}{r}24 \\
100.0 \%\end{array}$ \\
\hline & $101-200$ & $\begin{array}{l}\text { Count } \\
\% \text { within } \\
\text { Distance from } \\
\text { base station } \\
\end{array}$ & $3.4 \%$ & $31.0 \%$ & $37.9 \%$ & $6.9 \%$ & $20.7 \%$ & 29 \\
\hline & $\begin{array}{l}201 \mathrm{~m} \\
-300 \mathrm{~m}\end{array}$ & $\begin{array}{l}\text { Count } \\
\% \text { within } \\
\text { Distance from } \\
\text { base station }\end{array}$ & $4.8 \%$ & $19.0 \%$ & $23.8 \%$ & $42.9 \%$ & $9.5 \%$ & $\begin{array}{r}21 \\
100.0 \%\end{array}$ \\
\hline & $>300$ & $\begin{array}{l}\text { Count } \\
\% \text { within } \\
\text { Distance from } \\
\text { base station }\end{array}$ & $10.0 \%$ & $20.0 \%$ & $6.7 \%$ & $\begin{array}{r}11 \\
36.7 \%\end{array}$ & $26.7 \%$ & $100.0 \%$ \\
\hline Total & & $\begin{array}{l}\text { Count } \\
\% \text { within } \\
\text { Distance from } \\
\text { base station }\end{array}$ & $10.6 \%$ & $24.0 \%$ & $24.0 \%$ & $24.0 \%$ & $17.3 \%$ & $\begin{array}{r}104 \\
100.0 \%\end{array}$ \\
\hline
\end{tabular}


Table 7. Chi-Square Tests

\begin{tabular}{|l|r|r|r|}
\hline Fear of health problems & Value & Df & \multicolumn{2}{|c|}{$\begin{array}{c}\text { Asymp. Sig. } \\
\text { (2-sided) }\end{array}$} \\
\hline No Pearson Chi-Square & 8.606 & 12 & .736 \\
Likelihood Ratio & 9.323 & 12 & .675 \\
Linear-by-Linear Association & 2.284 & 1 & .131 \\
N of Valid Cases & 108 & & .006 \\
Yes Pearson Chi-Square & 27.693 & 12 & .004 \\
Likelihood Ratio & 29.188 & 12 & .075 \\
Linear-by-Linear Association & 3.177 & 1 & \\
N of Valid Cases & 104 & & \\
\hline
\end{tabular}

Table 8. Distance from base station and satisfaction with rent paid

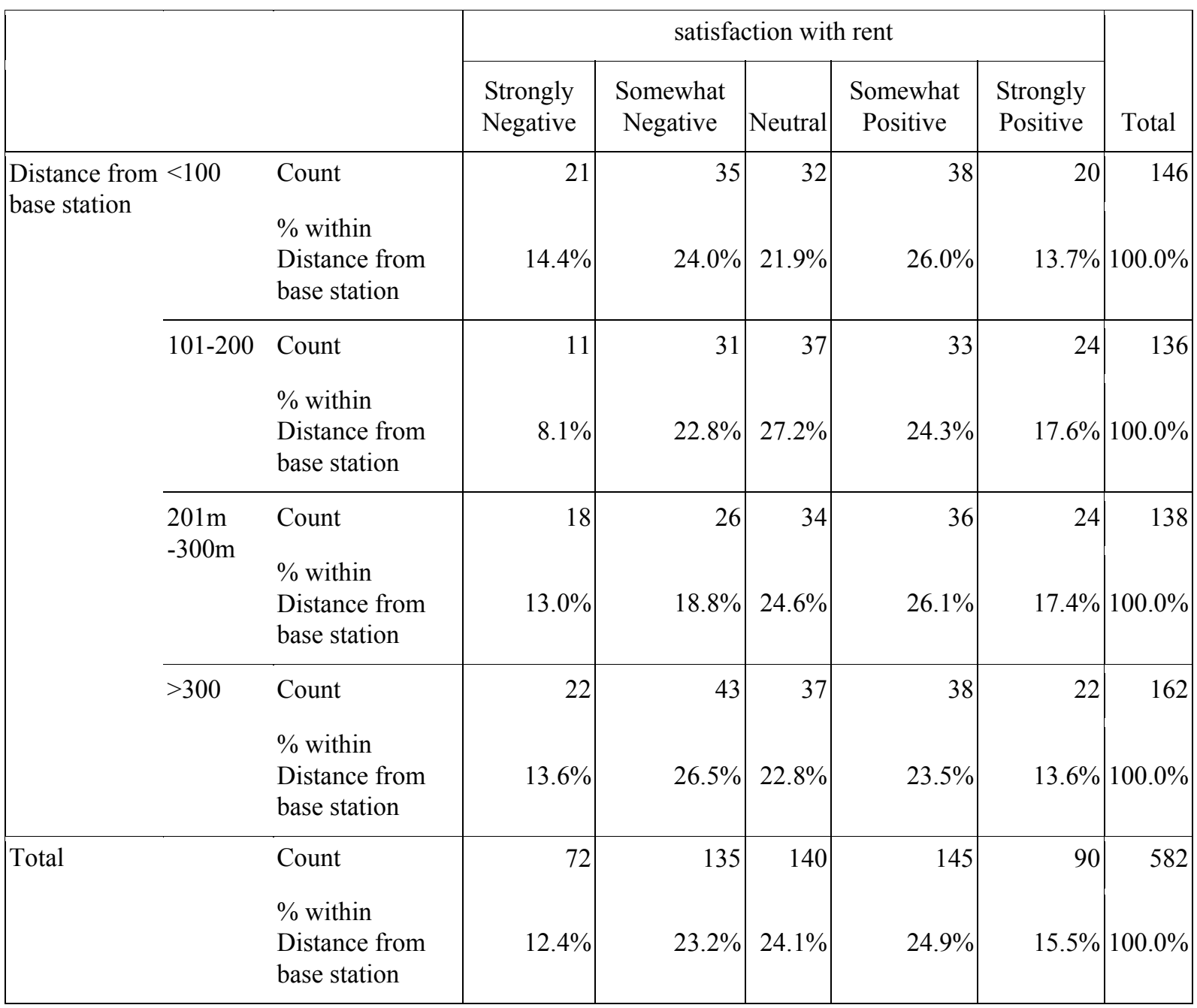


Table 9. Chi-Square Tests

\begin{tabular}{|l|r|r|r|}
\hline & \multicolumn{1}{|c|}{ Value } & Df & \multicolumn{1}{c|}{$\begin{array}{c}\text { Asymp. Sig. } \\
\text { (2-sided) }\end{array}$} \\
\hline Pearson Chi-Square & 7.379 & 12 & .832 \\
Likelihood Ratio & 7.659 & 12 & .811 \\
Linear-by-Linear & .161 & 1 & .688 \\
Association & 582 & & \\
N of Valid Cases & & & \\
& & & \\
\hline
\end{tabular}

Table 10. Satisfaction With Rent And Satisfaction With Base Station

\begin{tabular}{|c|c|c|c|c|c|c|c|c|}
\hline & \multicolumn{5}{|c|}{ satisfaction with base station } & \multirow[b]{2}{*}{ Total } \\
\hline & & & $\begin{array}{l}\text { Strongly } \\
\text { satisfied }\end{array}$ & $\begin{array}{l}\text { Somewhat } \\
\text { satisfied }\end{array}$ & Neutral & $\begin{array}{l}\text { Somewhat } \\
\text { not satified }\end{array}$ & $\begin{array}{l}\text { highly not } \\
\text { satisfied }\end{array}$ & \\
\hline \multirow[t]{5}{*}{$\begin{array}{l}\text { satisfaction } \\
\text { with rent }\end{array}$} & $\begin{array}{l}\text { Strongly } \\
\text { Negative }\end{array}$ & $\begin{array}{l}\text { Count } \\
\% \text { within } \\
\text { satisfaction with } \\
\text { rent }\end{array}$ & $4.2 \%$ & $25.0 \%$ & $20.8 \%$ & $25.0 \%$ & $25.0 \%$ & $\begin{array}{r}24 \\
100.0 \%\end{array}$ \\
\hline & $\begin{array}{l}\text { Somewhat } \\
\text { Negative }\end{array}$ & $\begin{array}{l}\text { Count } \\
\% \text { within } \\
\text { satisfaction with } \\
\text { rent }\end{array}$ & $7.0 \%$ & $32.6 \%$ & $25.6 \%$ & $20.9 \%$ & $14.0 \%$ & $100.0 \%$ \\
\hline & Neutral & $\begin{array}{l}\text { Count } \\
\% \text { within } \\
\text { satisfaction with } \\
\text { rent }\end{array}$ & $10.0 \%$ & 9 & 16 & $18.0 \%$ & 11 & 50 \\
\hline & $\begin{array}{l}\text { Somewhat } \\
\text { Positive }\end{array}$ & $\begin{array}{l}\text { Count } \\
\% \text { within } \\
\text { satisfaction with } \\
\text { rent }\end{array}$ & $13.6 \%$ & $28.8 \%$ & $21.2 \%$ & $25.8 \%$ & $10.6 \%$ & 66 \\
\hline & $\begin{array}{l}\text { Strongly } \\
\text { Positive }\end{array}$ & $\begin{array}{l}\text { Count } \\
\% \text { within } \\
\text { satisfaction with } \\
\text { rent }\end{array}$ & $10.3 \%$ & $31.0 \%$ & $6.9 \%$ & $31.0 \%$ & $20.7 \%$ & $100.0 \%$ \\
\hline Total & & $\begin{array}{l}\text { Count } \\
\% \text { within } \\
\text { satisfaction with } \\
\text { rent }\end{array}$ & $9.9 \%$ & 57 & 48 & 50 & 36 & 212 \\
\hline
\end{tabular}


Table 11. Chi-Square Tests

\begin{tabular}{|c|c|c|c|}
\hline & Value & Df & $\begin{array}{l}\text { Asymp. Sig. } \\
\text { (2-sided) }\end{array}$ \\
\hline Pearson Chi-Square & 15.082 & 16 & .519 \\
\hline Likelihood Ratio & 16.443 & 16 & .423 \\
\hline Linear-by-Linear Association & .694 & 1 & .405 \\
\hline $\mathrm{N}$ of Valid Cases & 212 & & \\
\hline
\end{tabular}

Table 12. Ordered Logit Regression on the Combined Effects of Distance, Fear and Satisfaction with Rent on the Satisfaction with Base Station Location.

\begin{tabular}{crrrr} 
& Coefficient & Std. Error & z-Statistic & Prob. \\
\hline \hline FEAR & 0.166620 & 0.246686 & 0.675435 & 0.4994 \\
DISTANCE & 0.263886 & 0.110654 & 2.384793 & 0.0171 \\
RENT & -0.080792 & 0.101794 & -0.793684 & 0.4274 \\
\hline \hline \multicolumn{5}{c}{ Limit Points } \\
\hline LIMIT_2:C(4) & -1.732668 & 0.500992 & -3.458476 & 0.0005 \\
LIMIT_3:C(5) & -0.048280 & 0.467967 & -0.103169 & 0.9178 \\
LIMIT_4:C(6) & 0.901270 & 0.475424 & 1.895719 & 0.0580 \\
LIMIT_5:C(7) & 2.139805 & 0.501134 & 4.269926 & 0.0000 \\
\hline \hline Akaike info criterion & 3.155763 & Schwarz criterion & 3.266593 \\
Log likelihood & -327.5108 & Hannan-Quinn criter. & 3.200558 \\
Restr. log likelihood & -330.7819 & Avg. log likelihood & -1.544862 \\
LR statistic (3 df) & 6.542165 & LR index (Pseudo-R2) & 0.009889 \\
Probability(LR stat) & 0.088014 & & \\
\hline \hline
\end{tabular}

